\title{
God Khenty irty
}

\author{
Mona Ezz Ali
}

Faculty of Tourism and Hotels, Mansoura University

\section{ARTICLE INFO}

Keywords:

Khenty irty; Khenty $\mathrm{n}$ irty; Mekhenty irty; Khem.

\section{(JAAUTH)}

Vol. 19, No. 1, (2020),

pp. 12-24.

\section{Abstract}

$\mathrm{He}$ is one of the falcon gods worshipped in Egypt, as many falcon gods worshipped through Egypt like Horus, Re, Re Horakhety, Montu, Sokar, Sopdu, Dedwen, Dwan anwi and Nemty. He is worshipped in khem (Letopolis). (M)Khenty irty is considered a universal god, whose eyes are the sun and the moon like god (Her wer). ${ }^{1}$ He was known also as (M) Khenty $n$ irty ${ }^{2}$ (the one without two eyes in his face) or the blind one. He has a dual nature, sighted and blind. He was worshipped as Khenty-Khem (foremost one of Khem). Khenty-irty is associated to god Her wer (the elder Horus), Shu, and god Montu. The research aims at Spotting light on god (m) Khenty (n) irty and its role in the Egyptian Religion. The study identifies the different forms of this deity and the different forms of his name, referring to the sacred texts, where (m) Khenty (n) irty is mentioned.

\section{Introduction}

Khem (letopolis): khem is the $2^{\text {nd }}$ name of Lower Egypt. The cult center of Khenty irty was there. It was known to the Greeks as letopolis, its modern name is Ausim. It is located about $12 \mathrm{Km}$ Northwest of Cairo, on the west bank of the Nile in the delta. According to the Egyptian Mythology Isis gave birth to Horus there, and the left arm of Osiris remained there. ${ }^{3}$ The four sons of Horus (Imesty, Kebehsenuf, Duatmutef and Hapy) were related with Khem, and they were known as the sons of Horus of Khem. It was known as the place of storm, thunderbolt, iron meteoric iron and flint, and all of them related mythological with the Northern sky. ${ }^{4}$ It was related closely with the ceremony of Opening of the mouth, as the chief priests of this ceremony wn $r$ lived there during Old Kingdom, as they easily got their ritual implement of this ceremony from there (city of thunderbolt). Indeed that the four sons of Horus, who are considered as sons of Horus of Khem, participated in this ceremony with their fingers of bi3. ${ }^{5}$

The name of Letopolis related to the worship of the great bear (mshtyw), so their standard was in the shape of foreleg of the bull $h p s$, which was the same representation for the constellation of the great bear. The four sons of Horus, who were worshiped in this name, were considered also as 4 stars at the constellation of the great bear and their father Khenty irty was the $7^{\text {th }}$ star, referring to the close relation between this constellation and the Letopolitan name. ${ }^{6}$ 


\section{The name}

Khenty irty or Mekhenty irty means the foremost of eyesight, or the one with two eyes in his face, or the one with sharp eyes. He is considered as a universal god, whose eyes are the sun and the moon. ${ }^{7} \mathrm{He}$ was known also as (M) Khenty $\mathrm{n}$ irty ${ }^{8}$ which means the one without two eyes in his face or the blind one, referring to the state of the sun and the moon in the set at the west ${ }^{9}$.

From the texts and the scenes, the name of $(m)$ Khenty $(n)$ irty was written in different ideograms: ${ }^{10}$

Pyr. 17,

\& 2 , Pyr.771,

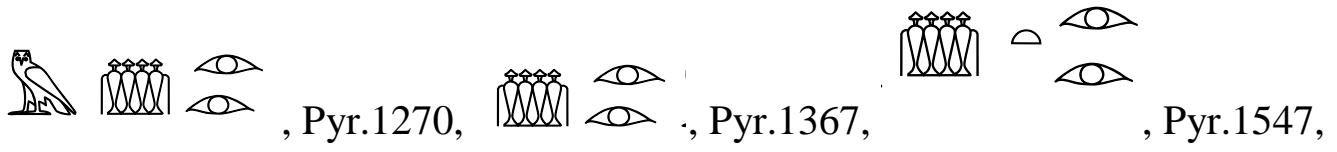

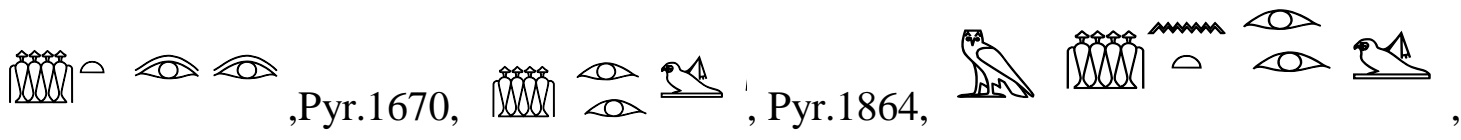

Pyr.2015,
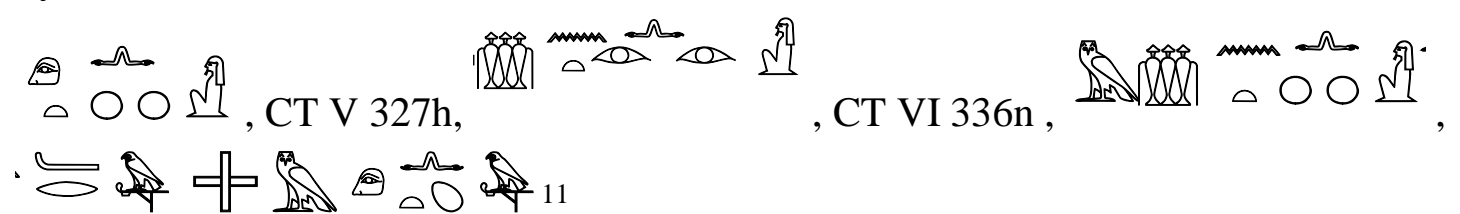

\section{Khenty irty in pyramid texts}

Khenty-irty is mentioned many times in the spells of pyramid texts like the following spells:

Pyr. $17^{12}$

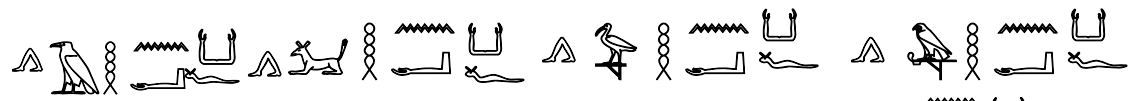

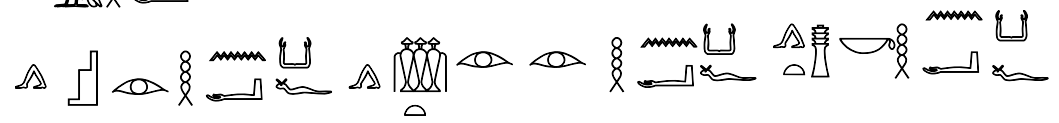

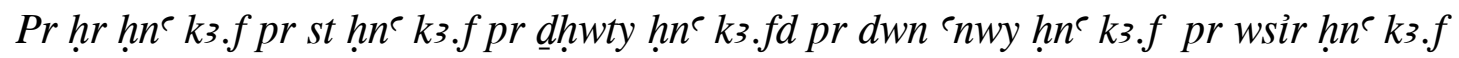

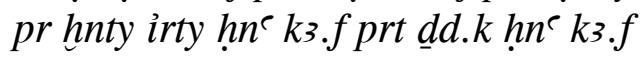

Horus goes with his double, Seth goes with his double, Thot goes with his double, Dwan anwi goes with his double, Osiris goes with his double and Khenty irty goes with his double, p.5 (libation spell) $)^{13}$

In this spell Khenty-irty is one of six gods mentioned as they are like the deceased, going with their double, and it refers that the king is like Horus, Seth, Thot, Dwan anwi, Osiris, and Khenty Irty, and all of them go with his double and he will be reunited with his force. ${ }^{14}$ 
Pyr. $148^{15}$

and

$m$ hnty. $k$ mhnty irty

Your face is Mekhenty irty

The face of the deceased is identified with Khenty-irty in this spell

Pyr .601. ${ }^{16}$

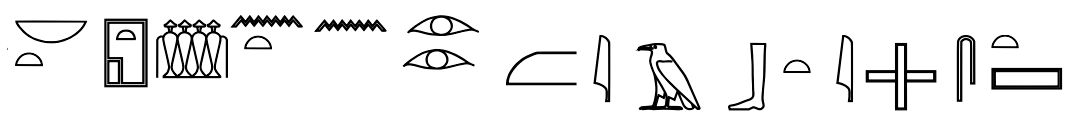

nbt ht hnty $n$ irty gs isbty st

Nephtys and Khenty irty are beside the left side, on which is Seth

In this spell Khenty-irty joins Nephtys and Seth at the left side of the deceased, corresponding to the four sons of Horus and Horus himself on the right side.

Pyr .771. ${ }^{17}$

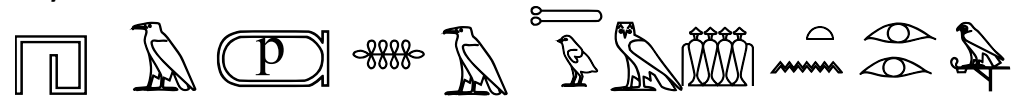

hз $N$ s 3 tw mhnty $n$ irty

O King, Mekhenty $n$ irty will protect you

This spell refers to the protection of Khenty irty to the deceased.

Pyr.82618

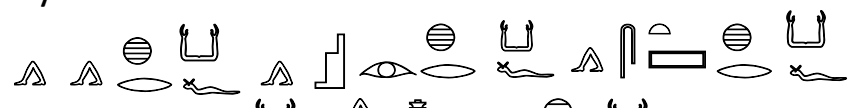

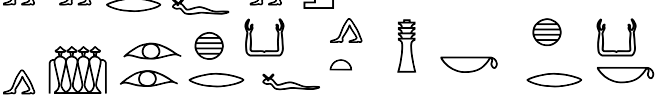

pri hr k3.f pr wsir h̆ k3.f pri st hr k3.f pri hnty irty hr k3.f prt $\underline{d} d$.k hr k3.k

(One) goes to his double, Osiris goes to his double, Seth goes to his double, Khenty irty goes to his double and the king goes to his double.

It implies that the king join his ka, referring to his rebirth after the separation which happen between the body and the ka in the period between the death and the burial. ${ }^{19}$ It refers also that the deceased in parallel with Osiris, Seth and Khenty $\mathrm{n}$ irty. ${ }^{20}$

Pyr.832 21

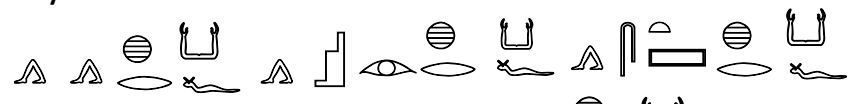

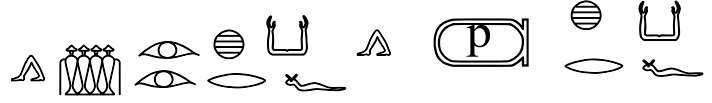

pr hr k3.f pr wsir hr k3.f pr st hr k3.f pr hnnty irty hr k3.f N hr k3.f

(One) goes to his double, Osiris goes to his double, Seth goes to his double, Khenty irty goes to his double and the king goes to his double, p. 149

Pyr.1211. 22

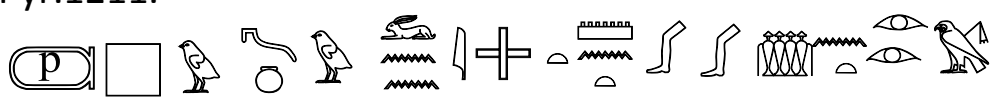

N pw nw wnn imyt mnt rdwy hnty irty

I am (the king) this one who was between the thighs of Khenty irty.

Pyr .1265. ${ }^{23}$ 
80 管

hrt hri tp twr mhnty irty mki dhwty

The tomb of the chieftain whom Mekhenty irty respects and Thot protects.

This spell to protect the tomb as Khenty-irty is one of four Gods (Isis, Nephtys, Khenty irty and Thoth), who shows the respect to the deceased and his tomb.

Pyr. 1367. ${ }^{24}$

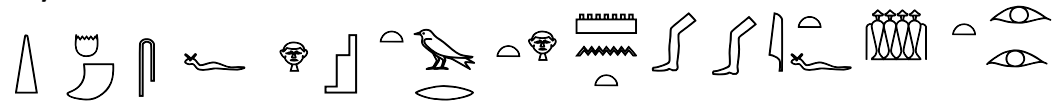

di hmsi. f hr st wrt hr mnt rdwy it.f hnty irty

May the king sit on the great throne on the thighs of his father Khenty irty

Pyr.1431. ${ }^{25}$

$\Delta h \Delta h_{0}^{\theta}$

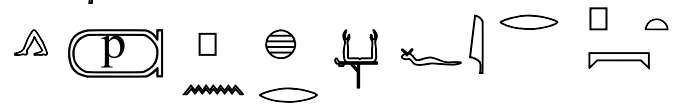

il il hr k3.f il mhnty irty hr k3.f ỉ N pn hr k3.f ir pt

(One) goes to his double, Mekhenty irty goes to his double and this king goes to his double towards the sky.

This spell indicates the importance of Mekhenty irty, who was mentioned in parallel to the deceased alone without the other deities mentioned with him in the similar spells (pyr. 17). ${ }^{26}$

Pyr.1547. ${ }^{27}$

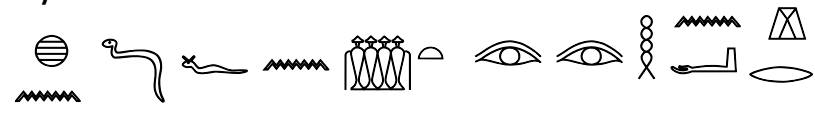

hnd. f $n$ hnty irty họ $\underline{\text { hrty }}$

Your legs belong to Khenty irty and kherty.

Pyr.1670. ${ }^{28}$

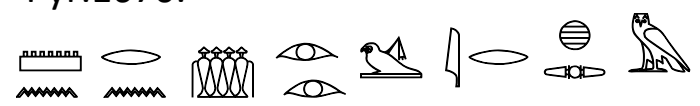

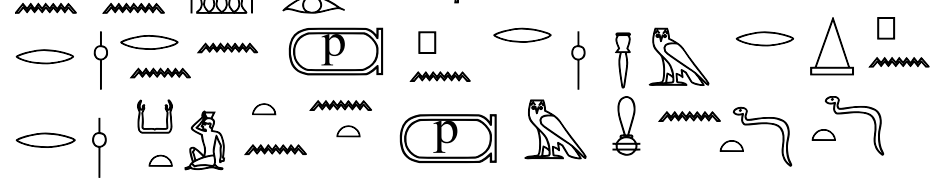

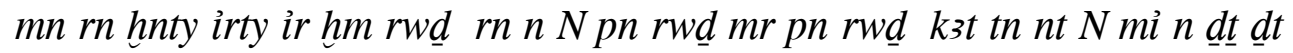

As the name of Khenty irty endures at khem, the king's name may endure, and his pyramid and his construction may endure likewise forever.

Pyr.1864. ${ }^{29}$

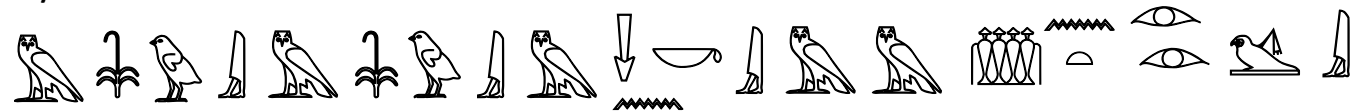
$m k s w$ il $m k$ sw il $m k$ sn.k il mk mhnty il

Behold, he has come, behold, he has come, behold, your brother has come, behold, Mekhenty irty has come.

Pyr.2015. 30 


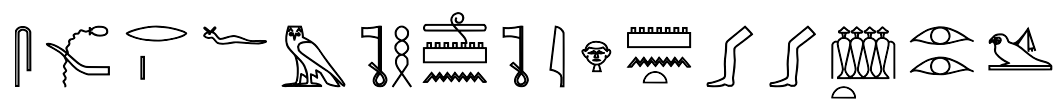

sebw r.f $m$ ḥsmn ḥr mnt rdwy hnty irty

His mouth (the mouth of the king) is cleansed with natron; he is purified on the thighs of Khenty irty

\section{Khenty irty in Coffin texts}

CTI 278, spell 65

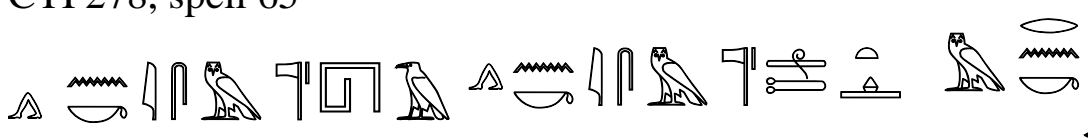

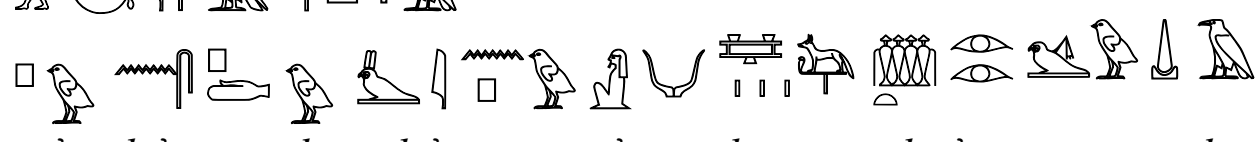

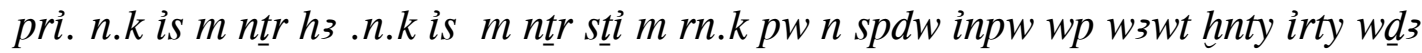

You have gone as a god, you have ascended as a god, being bandaged in this your name of Sopd, Anubis, Wepwawet and Khenty irty are those who make you very glad. ${ }^{31}$

CTII 114e, spell $105^{32}$

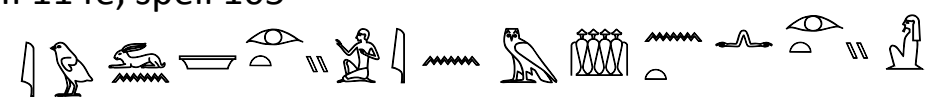

iw wn irty in mhnty $n$ irty

My eyes are opened by Mekhenty $n$ irty

CT II $117 \mathrm{f}$, spell $106^{33}$

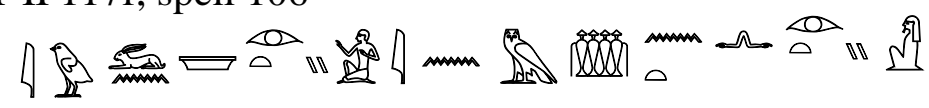

iw wn irty in mhnty $n$ irty

My eyes are opened by Mekhenty $n$ irty

CT III 20a, spell $167^{34}$

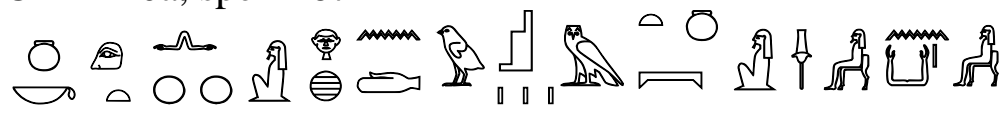

ink hnty $n$ irty hr hnndw $m$ pt shm.ì $n$ kz.i

I am Khenty $n$ irty, who is upon the throne of the sky. My power belongs to my double.

CT V 327h, spell $455^{35}$

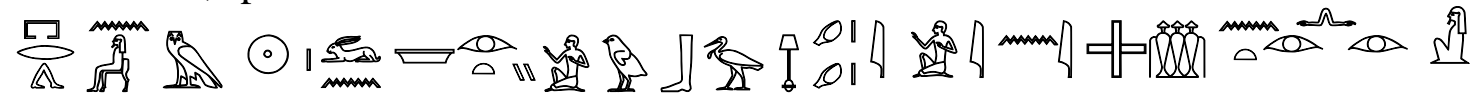
prỉ $n . i \mathrm{~m}$ hrw wn irty wb3 ms drty in mhnty $n$ irty

(When) I went out into the day. My eyes are opened, and my ears are opened by

Mekhenty $n$ irty.

CT VI 336n, spell $705^{36}$

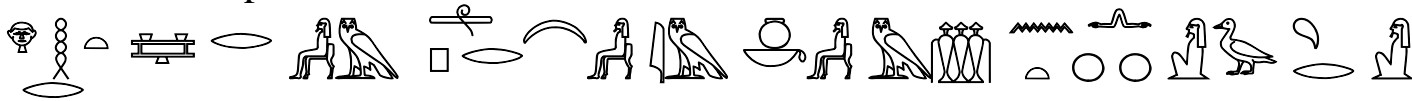

hr tì r i mspr im ink mhntỉ $n$ irty i sz wsir

Keep away from me, O. Mspr. I am Mekhenty $n$ irty (the eyeless one), the son of Osiris.

CT VII 22h, spell $821^{37}$

$\triangle 1000$

pri hnty irty hr k3.f

Khenty irty goes to his double. 


\section{Papyrus of Bremner- Rhind}

A Spell part of the book of throwing "Apo phis" at papyrus of Bremner-Rhind, in which Mekhenty irty punished " Apo phis" and his followers. ${ }^{38}$

min $\min _{0} \min _{0}$ amm

ntt.tn in hr mhnty irty

You are bound by Horus Mekhenty irty ${ }^{39}$

\section{Book of the Night}

At the lower register of the $7^{\text {th }}$ hour of the book of the Night god Horus says to his father Osiris.

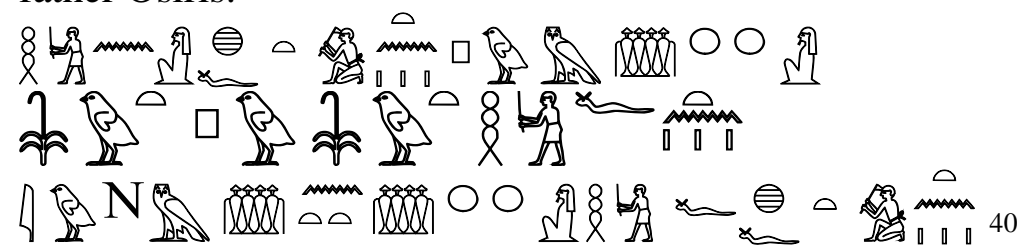

"ḥwi.n.ỉ hft.yw .tn pw m hnty irty swt pw swt ḥwỉ.f tn ỉw $N$ m hnty irty ḥwi.f hft.yw.tn"

I strike your enemy as Khenty irty, it is he who shall smite you, $\mathrm{N}$ is as Khenty irty, strikes your enemy"41

\section{Book of the Quererts}

In book of the Quererts at tomb of Ramses VI, God Re addressed gods within the sarcophagi saying 42

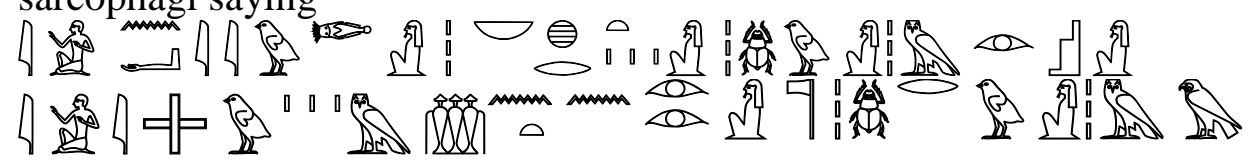

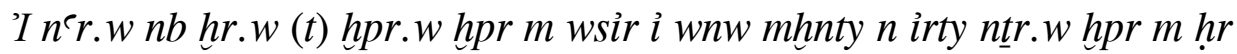

$\mathrm{O}$ catfish, lord of provisions, which comes from god Osiris. O those who exist as

Mekhenty irty, god who formed from Horus.

In other part of the book of the Quererts at tomb of Ramses VI, God Re addressed the mourners says 43

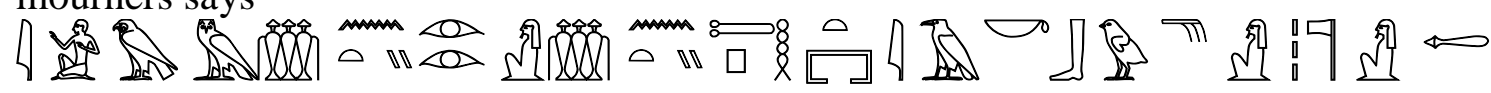

i ḥr mhnty $n$ irty hnty tph.t i iskbw ntr $3^{e}$

O Horus, Mekhenty irty, foremost of the cavern of mourning, the great god.

\section{Scenes of Khenty irty}

\section{Doc. 1}

Khenty irty is standing among the deities who follows god Anubis at Jumilhac Papyrus. $\mathrm{He}$ is represented in a human form, while holding a knife in both hands. He is the second god behind Anubis in the $1^{\text {st }}$ register. He is accompanied with his name $\bigcirc$ hnty $n$ irty ${ }^{44}$ fig. 1 


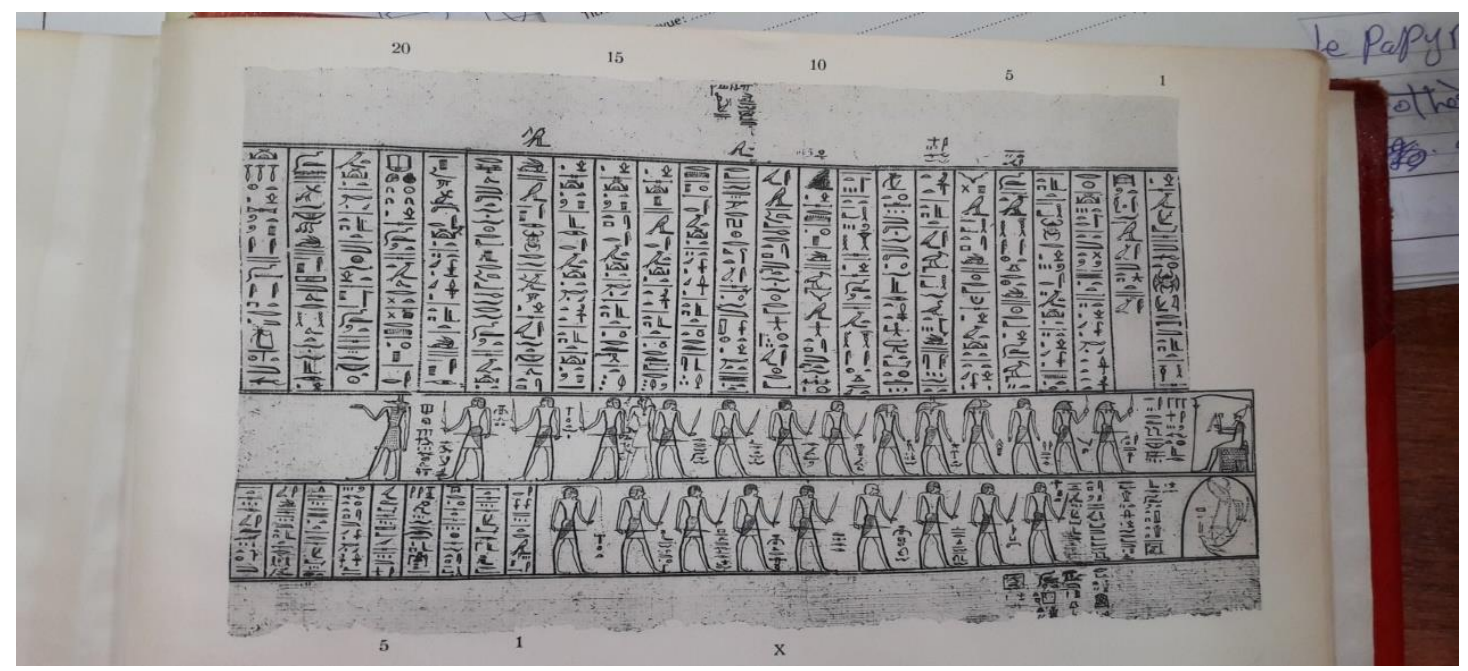

Fig.1. A scene representing god Khenty irty at papyrus Jumilhac, $19^{\text {th }}$ dynasty After J. Vandier, Le papyrus Jumilhac, Paris, 1961, pl. x

\section{Doc. 2}

God Khenty $n$ irty deities in the book of the day, tomb of Ramses IV at the $1^{\text {st }}$ register of the scene. He is the $3^{\text {rd }}$ god to the right side. ${ }^{45}$ fig. 2

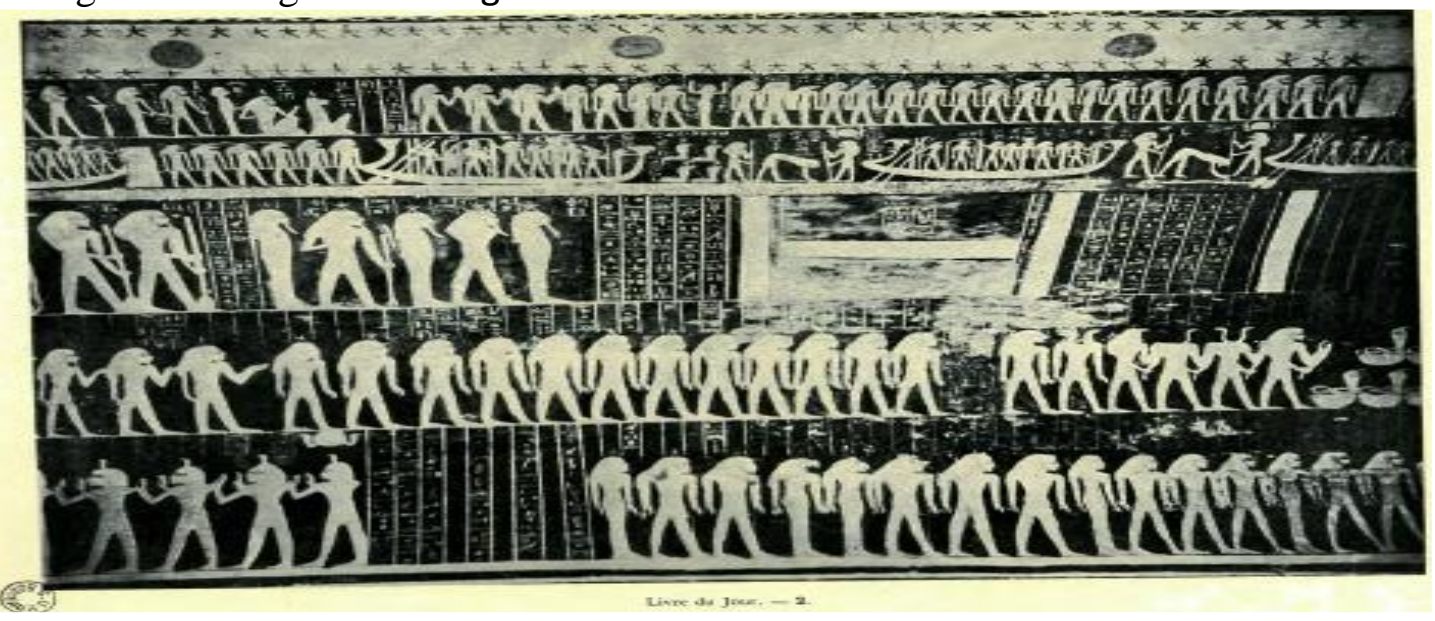

Fig.2. A scene representing Khenty irty among other standing gods. After A. Piankoff, Le livre du jour et de la nuit, le Caire, 1942, 7, pl. ii

Doc. 3

God Mekhenty $\mathrm{n}$ irty is represented at the $4^{\text {th }}$ section of the book of the caverns as a mongoose. He is considered here as the son of god Osiris who appeared here as a bull of the west. ${ }^{46}$ fig. 3

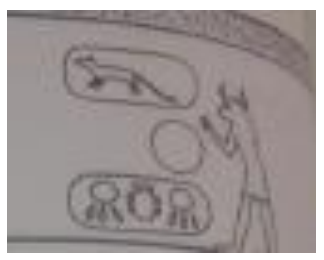

Fig. 3. A scene representing Mekhenty $n$ irty as a mongoose.

After E. Horning, the ancient Egyptian Books of the afterlife, London, 1999, fig. 50 


\section{Doc.4}

In many anthropoid coffins Khenty irty was represented as mummified god with a falcon head together with the four sons of Horus. For example the coffin of ist wrt at Cairo museum 23/1/21/9. Khenty irty appears in the $3^{\text {rd }}$ register behind ibis god $h r$ $b 3 k . f$, and the four sons of Horus stand at the $1^{\text {st }}$ and the $2^{\text {nd }}$ registers. ${ }^{47}$ fig. 4

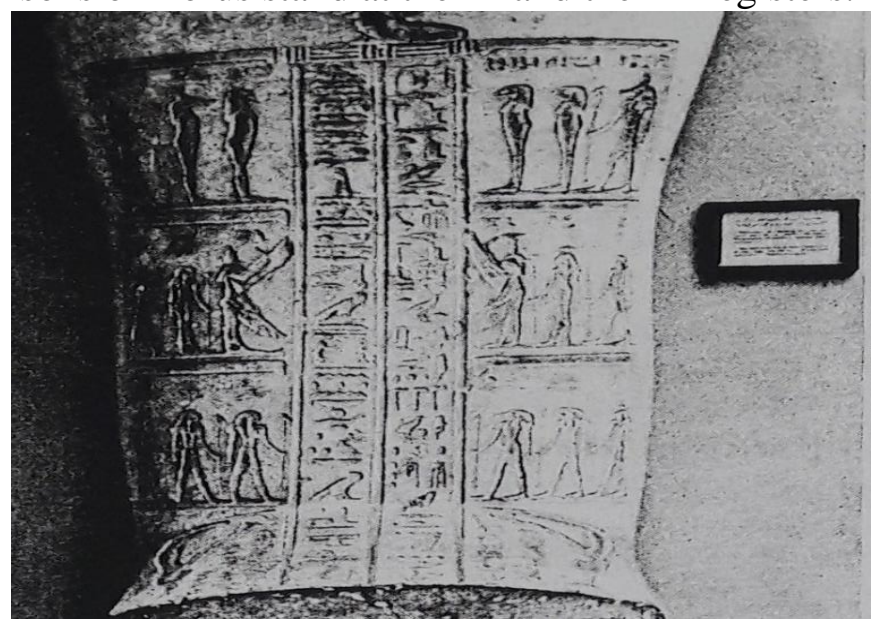

Fig.4. God Khenty irty appeared at the anthropoid coffin of ist wrt in the shape of falcon. After M.L Buhl, the late Egyptian Anthropoid Stone Sarcophagi, Kopenhavn, 1959, fig. 16

\section{Doc. 5}

Her Khenty $\mathrm{n}$ irty $\mathrm{O}^{-\Omega}$ appeared at another sarcophagus of $\mathrm{Hr}(\mathrm{w})$ at Cairo museum $\mathrm{n}^{\mathrm{o}} 35198$, dating to $30^{\text {th }}$ dynasty. He appears in the companion of four sons of Horus decorated the left shoulder of the lid. He appears at the $5^{\text {th }}$ register in the mummified form with falcon head. ${ }^{48}$ fig. 5

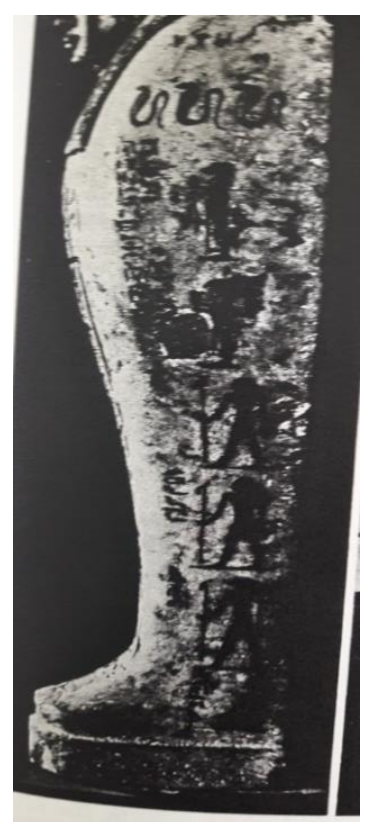

Fig.5. God Khenty irty appeared at the anthropoid coffin of $\mathrm{Hr}(\mathrm{w})$ in the shape of falcon After M.L Buhl, the late Egyptian anthropoid Stone Sarcophagi, Kopenhavn, 1959, fig. 67 


\section{Doc. 6}

God Khenty irty appears as a crocodile headed god holding the w3s and the ' $n h$ signs among other mummified gods in the southern chamber at Osirion at Abydos ${ }^{49}$ fig. 6

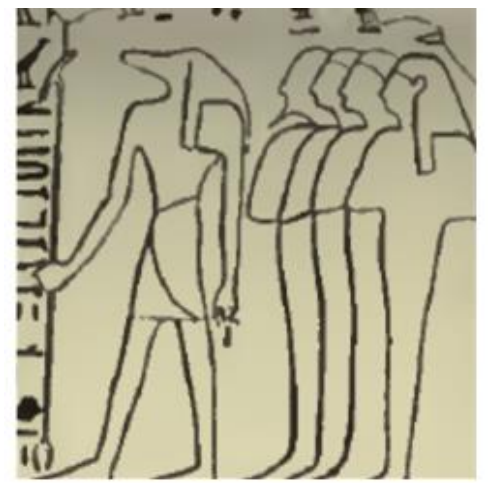

Fig.6. A scene representing Khenty irty as a crocodile headed god, osirion, $19^{\text {th }}$ dynasty

\section{Doc. 7}

After M. Murray, the Osireion at Abydos, London, 1904, pl. IV

God Khenty irty is represented as one of the gods of the ninth cave (ntrw krrt psdt nwt) in Papyrus BM 1. He appears as a crocodile headed god holding w3S scepter and ' $n h$ sign in the other hand ${ }^{50}$ fig.7

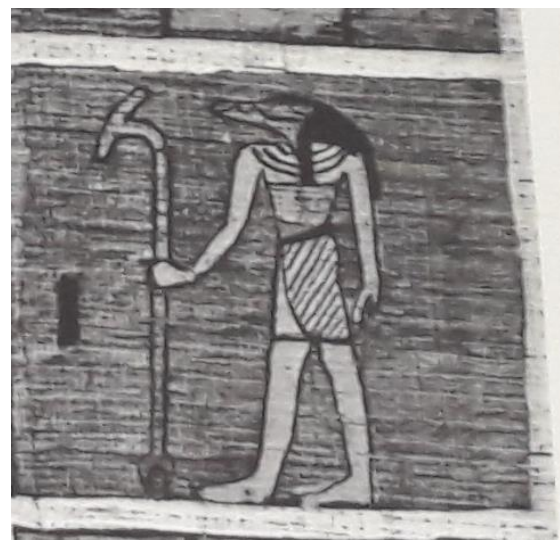

Fig.7 A scene representing Khenty irty as a crocodile headed god, Papyrus BM 1 After A. Piankoff, the Wandering of the Soul, Prineton, 1974, pl. 22

\section{His assimilation to other gods}

Montu: At the temple of Tod god Montu appeared as an ox, and it is accompanied with his name as $d \underline{y}$ to Khenty $n$ irty ${ }^{51}$

Horus wer: At the central hall of the temple of Kom Ombo god Horus wer appeared as a falcon headed god, and he is accompanied with his name as irty " Horus wer Khenty irty ${ }^{52}$ and other time he is accompanied with his name as 
Shu: At the temple of Kombo he designated to god Shu, who is called

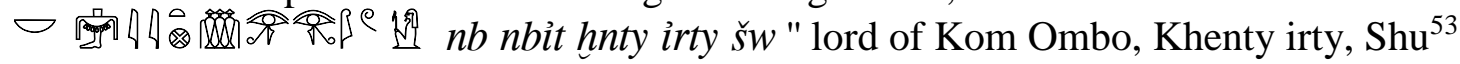

\section{The functions and roles of the god}

- One of the roles which this god played was to protect people from the blindness and cured them from the other diseases of the eye, because he had the ability to gain his sight after being blind he was also the one who cured the damaged eyes of god Re, so he became as doctor for the gods. ${ }^{54}$

- He helps the king to be an imperishable durable one as well as his pyramid and its construction (Pyr.1670, PT 601).

- He opens the eyes and the ears of the deceased to enable him to see and hear in the hereafter, and he purifies the deceased.

- He protects the deceased and his tomb.

- He punishes Apo phis and his companion at the spell of binding Apo phis

- He strikes the enemies of Osiris as if his son (seventh hour of the book of the night)

\section{Conclusion and results}

From this study it is concluded that:

- Khenty irty is considered as a universal god, whose eyes are the sun and the moon.

- (M) Mekhenty irty means the one with two eyes in his face, but his other form (M) Khenty $n$ irty means the blind one, referring to the state of the sun and the moon in the set at the west, so (M) Khenty $\mathrm{n}$ irty associated to The shrew mouse, the catfish and other blind animals lived under the ground, while (M) Khenty irty associated to the Ichneumon and other animals having sharp eyes.

The name of $(m)$ Khenty $(n)$ irty was written in different ideograms, and in several forms. It ends with one of the following determinatives,

- god Khenty irty appeared in different forms as he appeared as a falcon headed god, a crocodile headed god, and in a human form, indeed that Khenty $n$ irty appeared in some cases as a mongoose

- He was assimilated to god Her wer, Montu, and god Shu.

- He is considered the father of four sons of Horus, and both of them are considered as stars in the constellation of the great bear.

- Khenty irty was worshipped together with the four sons of Horus at khem (Letopolis) which was related closely with the ceremony of Opening of the mouth, and he was mentioned at the pyramid texts as the one who helps in opening the eyes and ears of the deceased to enable him to see and hear easily in the hereafter, so that he appeared in the scenes decorated anthropoid coffins in the companion of the four sons of Horus

- God Khenty irty was mentioned in many sacred texts like spells of pyramid texts, coffin texts, and book of the day and the night.

- it is concluded from the studied sacred texts that The face of the deceased is identified with Khenty-irty, he protects the deceased, he is one of four gods who shows the respect to the deceased and his tomb, the Permanence of the name and the pyramid of the king was related to the endurance of the Khenty irty's name, Khenty-irty is one 
of six gods mentioned as they are like the deceased king, going with their doubles, and he will be reunited with his force. He is considered as the father of the deceased king and in other spell he is considered as his brother, the king is purified on the thighs of Khenty irty, and he is upon the throne of the sky, and his power belongs to his double, and he is considered as son of Osiris like Horus.

- He protects people from the blindness and cured them from the other diseases of the eye, and he became as doctor for the gods. ${ }^{55}$

- He helps the king to be a durable one as well as his pyramid and its construction (Pyr.1670, PT 601).

- He opens the eyes and the ears of the deceased to enable him to see and hear in the hereafter, and he purifies the deceased.

- He protects the deceased and his tomb.

- He punishes Apo phis and his companion at the spell of binding Apo phis

- He strokes the enemies of Osiris as if his son (seventh hour of the book of the night)

\section{Bibliography:}

1 David Klotz, Adoration of the Ram : five hymns to Amun-Re from Hibis temple, New haven, 2006, 161 2 (M)khenty $\mathrm{n}$ irty associated to The shrew mouse and other blind animals lived under the ground, while (M)khenty irty associated to the Ichneumon and other animals having sharp eyes; see A. K. Eyma, C. J. Bennett, A Delta-man in Yebu, Canada, 2003, 218

${ }^{3}$ R. Bauval, secret chamber revisited. Quest for the lost knowledge of ancient Egypt, London, 2014, 72

${ }^{4}$ C Graves Brown, Daemons and Spirits in Ancient Egypt, Cardiff, 2018, 109

${ }^{5}$ G. A. Wainwright, " Iron in Egypt", JEA 18, 1932 , 6

${ }^{6}$ Id., " Letopolis", JEA 18, 1932 , 163

7 D. Klotz, Adoration of the Ram : five hymns to Amun-Re from Hibis temple, New haven, 2006, 161 8 (M)khenty $n$ irty associated to The shrew mouse and other blind animals lived under the ground, while (M)khenty irty associated to the Ichneumon and other animals having sharp eyes; see A. K. Eyma, C. J. Bennett, A Delta-man in Yebu, 218

9 R.Weil, " Notes sur l'histoire primitive des grandes religions égyptiennes", 104-105

${ }^{10}$ CHR. LEITZ, Lexicon der Ägyptischen Götter und Götterbezeichnung III, OLA 112, ( Leuven- Paris, 2002),394

${ }^{11}$ R.O. Faulkner, the papyrus Bremner-Rhind, , 22, 20

${ }^{12}$ Pyr. 17, pt 25

${ }^{13}$ N. Billing, The Performative Structure: Ritualizing the Pyramid of Pepy I, Leiden, 2013, 194

${ }^{14}$ R.Weil, " Notes sur l'histoire primitive des grandes religions égyptiennes", BIFAO 47, Le Caire, 1974,106

${ }^{15}$ Pyr.148, pt 215

${ }^{16}$ Pyr.601, pt 359

${ }^{17}$ Pyr.771, pt 424

${ }^{18}$ Pyr.826, pt 447

${ }^{19}$ N. Billing, The Performative Structure, 151

${ }^{20}$ R.Weil, " Notes sur l'histoire primitive des grandes religions égyptiennes",106

${ }^{21}$ Pyr.832, pt 450

${ }^{22}$ Pyr.1211, pt 519

${ }^{23}$ Pyr.1265, pt 534

${ }^{24}$ Pyr.1367, pt 553

${ }^{25}$ Pyr.1431, pt 568 
${ }^{26}$ R.Weil, " Notes sur l'histoire primitive des grandes religions égyptiennes", 1974,106

${ }^{27}$ Pyr.1547, pt 580

${ }^{28}$ Pyr.1670, pt601

${ }^{29}$ Pyr.1864, pt 659

${ }^{30}$ Pyr.2015, pt 676

${ }^{31}$ R. O. FAULKNER, The Ancient Egyptian Coffin Texts I, (Warminstar, 1973), 60

${ }^{32}$ Ibid., 104

${ }^{33}$ Ibid., 109

${ }^{34}$ Ibid., 144

${ }^{35}$ R. O. FAULKNER, The Ancient Egyptian Coffin Texts II, (Warminstar, 1977), 86

${ }^{36}$ Ibid., 266

${ }^{37}$ R. O. FAULKNER, The Ancient Egyptian Coffin Texts III, (Warminstar, 1978), 11

${ }^{38}$ S.L. Colledge, the process of Cursing in Ancient Egypt, Liverpool, 2015, 268.

${ }^{39}$ R.O. Faulkner, Bibliotheca Aegytiaca III. the papyrus Bremner- Rhind, Bruxelles, 1993, 22, 20

${ }^{40}$ G. Roulin, le livre de la Nuit II, Zürich, 1996, 90-91

${ }^{41} \mathrm{C}$. Manassa, the late Egyptian underworld: Sarcophagi and related Texts from the Nectanebid Period, Wiesbaden, 2007, 141.

${ }^{42}$ A. Piankoff, " le livre des Quererts 2", BIFAO 42,1942, 5, PL. XII

${ }^{43}$ Ibid., 7, pl. xv

${ }^{44}$ J. Vandier, Le papyrus Jumilhac, Paris, 1961, pl. x

${ }^{45}$ A. Piankoff, Le livre du jour et de la nuit, le Caire, 1942, 7, pl. ii

${ }^{46}$ E. Hornung, the ancient Egyptian Books of the afterlife, London, 1999, 87

47 M.L Buhl, the late Egyptian anthropoid Stone Sarcophagi, Kopenhavn, 1959, 50, fig. 16

${ }^{48}$ G. Darressy," un Sarcophage de Gaou", ASAE IV, le caire, 1903, 121

${ }^{49}$ M. Murray, The Osireion at Abydos, London, 1904, pl. iv

50 A. Piankoff, The Wandering of the Soul, Prineton, 1974, pl. 22

51 É Drioton, G. Posener, and J. Vandier, Tôd : Les inscriptions du temple ptolémaïque et romain. La salle hypostyle, le Caire, 1980, 62

52 A. Gutbub, Kôm Ombo I. Les inscriptions du naos , Le Caire, 1995, 61

53 Ibid., 243

54 A. K. Eyma, C. J. Bennett , A Delta-man in Yebu, 218

55 A. K. Eyma, C. J. Bennett, A Delta-man in Yebu, 218 


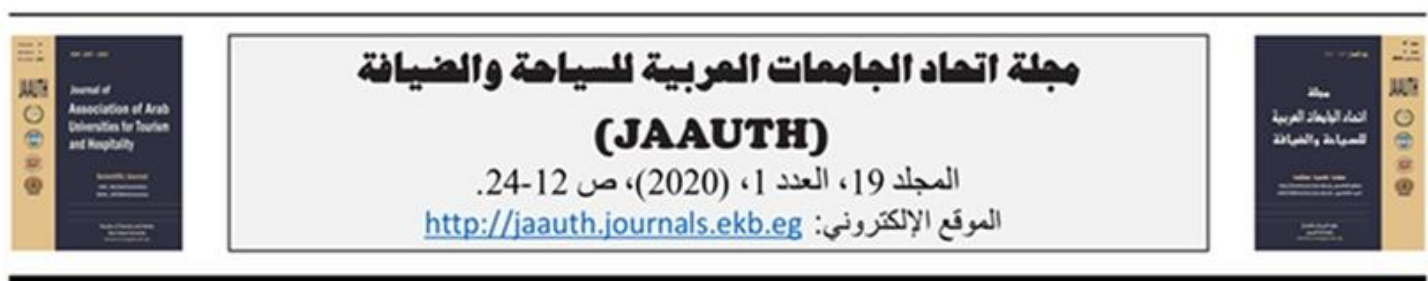

\section{المعبود خنتي إيرتي}

منى عز الدين

كلية السياحة و الفنادق جامعة المنصورة

العالماتوات المفتامية

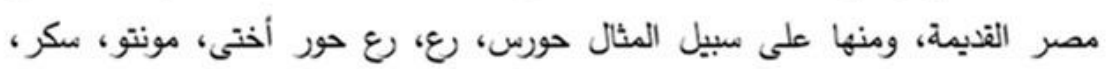

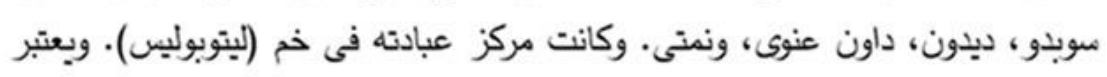

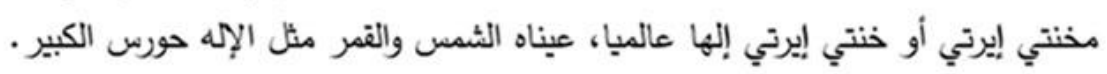

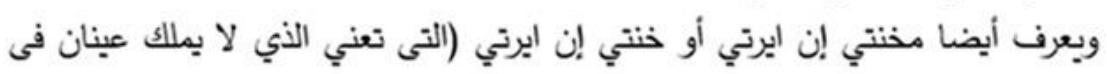

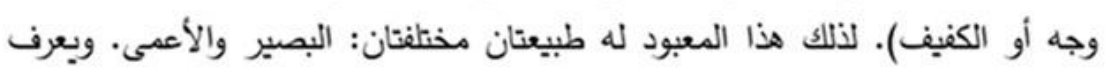

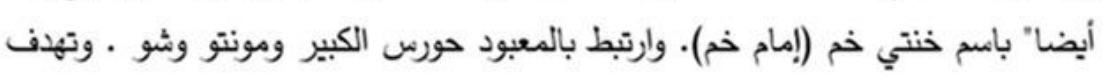

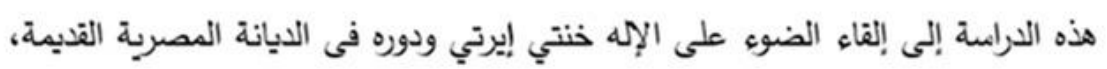
خنتى إرتى؛ خنتى إن إرتى؛ مخنتى إرنى؛

(JAAUTH) المجلد 19، العذد 1، ،(2020) ص 24-12.

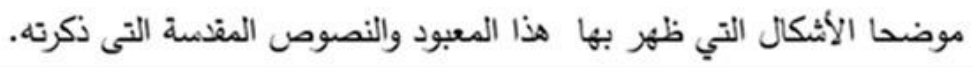

